\title{
CoNiP/NC polyhedrons derived from cobalt-based zeolitic imidazolate frameworks as an active electrocatalyst for oxygen evolution
}

\author{
Jintang Li *, Guiqing Du, Xian Cheng, Pingjing Feng, Xuetao Luo \\ Fujian Key Laboratory of Advanced Materials, College of Materials, Xiamen University, Xiamen 361005, Fujian, China
}

\section{A R T I C L E I N F O}

\section{Article history:}

Received 19 December 2017

Accepted 21 January 2018

Published 5 May 2018

\section{Keywords:}

ZIF-67

Carbonization

Phosphorization

Electrocatalyst

Oxygen evolution reaction

\begin{abstract}
A B S T R A C T
The oxygen evolution reaction (OER) plays an important role in the development of energy conversation and storage technologies including water splitting and metal-air batteries, where the development of electrocatalysts is paramount. In this study, cobalt-nickel phosphide/N-doped porous carbon polyhedron electrocatalysts (CoNiP/NC) were prepared by a facile two-step carbonization method and subsequent phosphorization calcination in an Ar atmosphere using cobalt-based zeolitic imidazolate frameworks (ZIFs) as precursors. Among the electrocatalysts obtained by controlling the carbonization and phosphorization temperature, the CoNiP/NC700 catalyst, where 700 refers to the calcination temperature $\left({ }^{\circ} \mathrm{C}\right)$, exhibited superior electrocatalytic activity for the OER with an onset overpotential of approximate $220 \mathrm{mV}$ and an overpotential of approximate $300 \mathrm{mV}$ in alkaline solution at a current density of $10 \mathrm{~mA} / \mathrm{cm}^{2}$. The CoNi/NC and Co/NC Samples were also tested for comparison and CoNiP/NC exhibited the better electrocatalytic activity at all the temperatures tested. The superior electrocatalytic activity of the phosphorization hybrid material can be attributed to the superior synergistic effect of $\mathrm{Co}, \mathrm{Ni}, \mathrm{P}$ and $\mathrm{C}$ due to their strong electron coupling interactions. The interconnected amorphous carbon anchored the active Co compounds to avoid aggregation and maintained conducting channels for electron transfer. The composite electrocatalyst prepared herein is a promising candidate for use in electrocatalytic OERs.
\end{abstract}

(C) 2018, Dalian Institute of Chemical Physics, Chinese Academy of Sciences. Published by Elsevier B.V. All rights reserved.

\section{Introduction}

Recently, the depletion of fossil fuels and the associated exponential rise in global warming have stimulated considerable interest in alternative sources of renewable energy production and conversion [1,2]. The oxygen evolution reaction (OER), a half reaction involving electrochemical water splitting, has attracted considerable attention due to its critical role in water splitting and metal-air batteries and for hydrogen production and metal regeneration $[3,4]$. High electrochemical overpotential typically results from the kinetically sluggish four-electron oxidation reaction at the anode [5]. Ruthenium and iridium oxides have been developed as the most efficient electrocatalysts for the OER to date due to their low overpotentials and high proton mobility efficiency. However, their high cost, scarce reserves, and poor durability considerably prohibit more extensive applications [6]. To reduce the reaction overpotentials and obtain good reaction rates with reduced input energy, the

\footnotetext{
*Corresponding author. Tel: +86-18030105513; E-mail: leejt@xmu.edu.cn

This work was supported by National Natural Science Foundation of China (51204143, 51334004) and the Scientific and Technological Innovation Platform of Fujian Province (2006L2003).

DOI: 10.1016/S1872-2067(18)63030-X | http://www.sciencedirect.com/science/journal/18722067 | Chin. J. Catal., Vol. 39, No. 5, May 2018
} 
development of effective non-precious metal electrocatalysts with high activity and low cost is required [7]. To date, some efficient alternatives OER catalysts in alkaline electrolytes using noble metal-based non-precious electrocatalysts including layered double hydroxides [8,9], sulfides [10,11], transition-metal oxides [12], hydroxides [13], metal free catalysts [14] and phosphate [15] have been reported [16].

Among different electrocatalysts for OER, metal-organic frameworks (MOFs), and in particular zeolitic imidazolate frameworks (ZIFs), have gained attention as novel sacrificial templates to construct efficient porous carbon-based electrocatalysts [17]. These materials have been widely used in gas storage or separation [18], catalysis [19], $\mathrm{CO}_{2}$ reduction [20], and water-splitting [21] because of their excellent chemical and physical properties including high specific surface area, large number of active sites (an active site means the point where catalysis reaction can happen) [22], and tunability of both metals and ligands in the MOFs [23]. MOFs have been used as precursors to synthesize OER catalysts because of their controllable porous structure and nearly infinite design possibilities. In addition, various MOF-derived carbon-based porous metal compounds can be obtained through direct carbonization without further processing or templating. Among cobalt-based MOF materials, ZIF-67 is one of the most investigated MOFs and offers a large number of active cobalt sites. For example, carbonization of ZIF-67 results in a porous Co@N-doped carbon composite (named N/Co-doped PCP//NRGO), which is very active toward the water splitting reaction [24]. In this study, we demonstrate a facile MOF-derived approach for the effective synthesis of OER electrocatalysts in $1.0 \mathrm{~mol} / \mathrm{L}$ of $\mathrm{KOH}$, producing CoNiP/NC derived from ZIF-67 and doped with nickel through a two-step carbonization and phosphorization calcination precedure in Ar atmosphere. Compared to a previous report of the phosphatization of sodium hypophosphite [25], the strategy described herein of simultaneous carbonization and phosphorization calcinations of Ni-doped ZIF-67 can more easily yield CoNiP/NC hybrid composites. These results suggest that the MOF-derived CoNiP/NC is a promising electrocatalysts for the OER for water splitting in alkaline electrolytes. The $\mathrm{N}$-doped cobalt nickel phosphorus porous carbon electrocatalysts CoNiP/NC, and CoNiP/NC700, where 700 referrs to the calcination temperature $\left({ }^{\circ} \mathrm{C}\right)$, exhibited superior activity towards oxygen evolution with an onset overpotential of approximately $220 \mathrm{mV}$ and an overpotential of approximately $300 \mathrm{mV}$ in alkaline solution at a current density of 10 $\mathrm{mA} / \mathrm{cm}^{2}$. The better electrocatalytic activity of the hybrid material can be attributed to the superior synergistic effect of Co, $\mathrm{Ni}, \mathrm{P}$ and $\mathrm{C}$ due to their strong electron coupling interactions. The interconnected amorphous carbon anchored the active Co compounds preventing aggregation and afforded conducting channels for electron transfer.

\section{Experimental}

\subsection{Formation of CoNiP/NC}

In total, $0.5 \mathrm{~g}$ of ZIF-67 particles were dispersed in $200 \mathrm{~mL}$ of ethanol containing $1 \mathrm{~g}$ of nickel nitrate hexahydrate. After stirring for $30 \mathrm{~min}$, the ZIF-67Ni yolk-shelled particles were formed, collected by centrifugation (at $9000 \mathrm{r} / \mathrm{min}$ for $10 \mathrm{~min}$ ), and dried at $50{ }^{\circ} \mathrm{C}$ for $5 \mathrm{~h}$. Subsequently, the CoNi/NCx, which $x$ refers to the calcination temperature $\left({ }^{\circ} \mathrm{C}\right)$, were obtained by annealing the as-obtained yolk-shelled particles at temperatures of $600,700,800,900$, and $1000{ }^{\circ} \mathrm{C}$ for $3 \mathrm{~h}$ at a ramp rate of $5{ }^{\circ} \mathrm{C} /$ min under an Ar atmosphere. To obtain CoNiP/NCx, 50 mg CoNix and 1.0 g sodium hypophosphite were placed at two separate positions in a combustion boat and subjected to phosphidation at $300{ }^{\circ} \mathrm{C}$ for $2 \mathrm{~h}$ at a ramp rate of $5{ }^{\circ} \mathrm{C} / \mathrm{min}$ under an Ar atmosphere.

\subsection{Characterization}

The obtained samples were characterized using powder X-ray diffractometry (XRD, Bruker-AxsD8) with $\mathrm{Cu} K_{\alpha}$ radiation $(\lambda=0.15406 \mathrm{~nm})$ at $2 \theta=5^{\circ}-70^{\circ}$, operating at a voltage of $40 \mathrm{kV}$ and current of $40 \mathrm{~mA}$. The morphologies of the samples were characterized by field emission-scanning electron microscope (FE-SEM, Hitachi SU-70) operating at $10 \mathrm{kV}$. The samples used for SEM imaging were gold sputtered prior to analysis. X-ray photoelectron spectroscopy (XPS) data were acquired on an ESCALAB 250Xi X-ray photoelectron spectrometer (Thermo Scientific) using $\mathrm{Al} K_{\alpha}$ radiation.

\subsection{Electrochemical measurements}

Cyclic voltammetry (CV) and linear sweep voltammetry (LSV) measurements were performed on an Autolab electrochemical workstation (NOVA 1.9). To prepare the electrodes for OER testing, $5 \mathrm{mg}$ of active material was added to a mixture of $1.9 \mathrm{~mL}$ ethanol and $0.1 \mathrm{~mL}$ Nafion solution with sonication for $60 \mathrm{~min}$. Subsequently, the catalyst $(20 \mu \mathrm{L})$ was pipetted out and dropped onto a glassy carbon electrode with a diameter of $5 \mathrm{~mm}$ and fully dried at room temperature for $12 \mathrm{~h}$ before measurements were taken (loading of $\sim 0.255 \mathrm{mg} / \mathrm{cm}^{2}$ ). The electrochemical cell was assembled as a conventional three-electrode system with electrochemical workstation in KOH solution $1.0 \mathrm{~mol} / \mathrm{L}$. The counter and reference electrodes were composed of a Pt foil and an $\mathrm{Ag} / \mathrm{AgCl}$-saturated $\mathrm{KCl}$ electrode, respectively, and a glassy carbon electrode (GCE, $5 \mathrm{~mm}$ in diameter) was used as the working electrode. All measured potentials were normalized to the reversible hydrogen electrode (RHE) by adding a value of $(0.197+0.059 \mathrm{pH}) \mathrm{V}$. A scan rate of $10 \mathrm{mV} / \mathrm{s}$ was used in the linear sweep voltammetry to

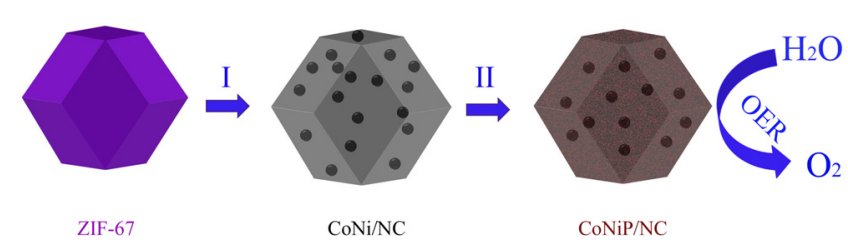

Fig. 1. Schematic diagram illustrating the OER catalytic principles on CoNiP /NC polyhedrons. Step I: transformation of ZIF-67 into CoNi/NC by a facile etching and deposition process and carbonization; Step II: formation of CoNiP/NC by phosphatizing CoNi/NC. 
obtain the polarization curves, $1.0 \mathrm{~V}-1.8 \mathrm{~V}$.

\section{Results and discussion}

Fig. S1 (Supporting Information) shows the XRD patterns of ZIF-67-Simulated, ZIF-67, ZIF-67Ni, Co/NC700, CoNi/NC700, and CoNiP/NC700 samples. Compared to the simulated data of ZIF-67, the ZIF-67 precursor has similar diffraction peaks, indicating the successful synthesis of ZIF-67 [26]. The XRD patterns of ZIF-67Ni is similar to that of ZIF-67 [27]. The standard spectral data of Co (PDF \#01-1255) and Ni (PDF \#71-2336) exhibit the same diffraction peaks as these of Co/NC700 and CoNi/NC700. According to the CoNiP standard (PDF \#71-2336) spectrum shown in Fig. 2(f), the CoNiP/NC700 was successfully synthesized. However, it is difficult to ascertain the exact stoichiometry of CoNiP/NC because the polymorphs of cobalt nickel phosphides contains several types; $\mathrm{Co}_{1.49} \mathrm{Ni}_{0.51} \mathrm{P}$ (ICDD No. 04-019-5182), Co1.4Nio.6P (ICDD No. 04-005-5616), and CoNiP (ICDD No. 04-001-4562). Furthermore, the various XRD patterns obtained under different conditions are shown in Fig. S1.

The SEM image in Fig. 2(a) indicates that ZIF-67 is a regular polyhedron with an obvious edge and diameter of approximately $700 \mathrm{~nm}$. Fig. 2(c) shows that ZIF-67Ni conserves polyhedron shape, but with a rougher surface due to the reaction with $\mathrm{Ni}\left(\mathrm{NO}_{3}\right)_{2}$ in ethanol solution for $30 \mathrm{~min}$. The CoNi/NC700 obtained by the calcination of ZIF-67Ni in Ar for $3 \mathrm{~h}$ at $700{ }^{\circ} \mathrm{C}$ was shown Fig. 2(d). The size and shape of the final product, CoNiP/NC700, was largely unchanged after subsequent phosphidation step for $300{ }^{\circ} \mathrm{C}$ (Fig. 2(e)). With higher calcination temperatures, more serious ZIF-67 deformation occurs. Furthermore, the various SEM images obtained under different
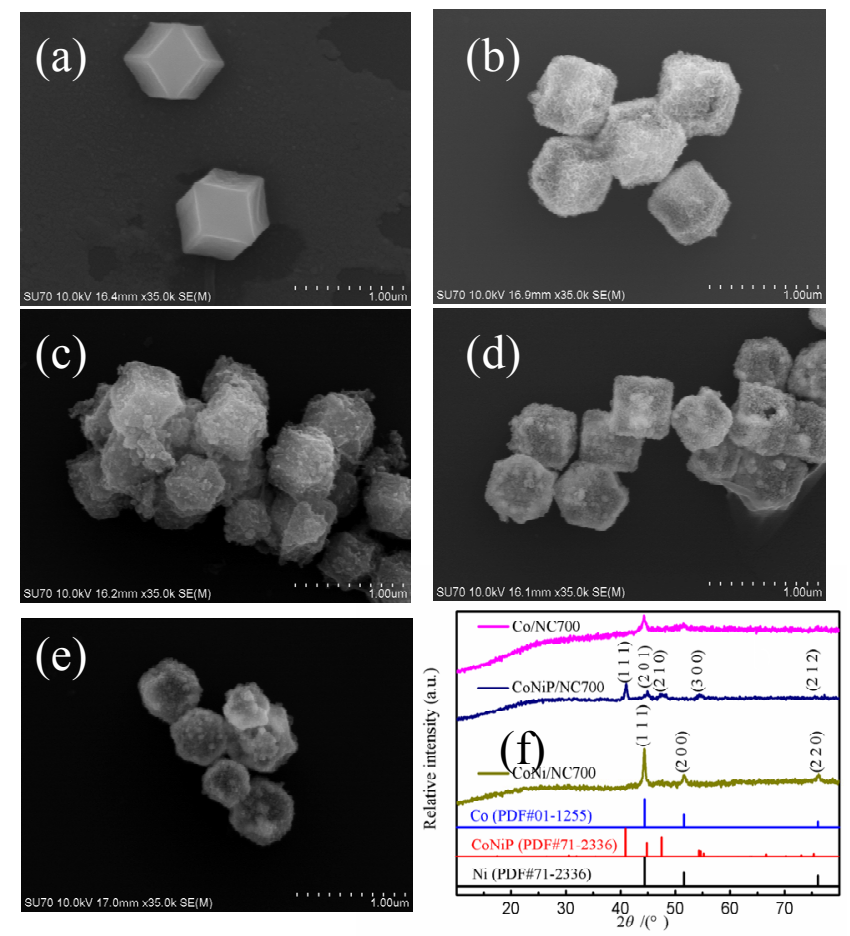

Fig. 2. SEM images of ZIF-67 (a), ZIF-67Ni (b), Co/NC700 (c), Co$\mathrm{Ni} / \mathrm{NC700}(\mathrm{d}), \mathrm{CoNiP} / \mathrm{NC700}$ (e) and their corresponding XRD patterns (f).

conditions are shown in Fig. S2.

To determine the detailed elemental composition, valence state, and OER activity of $\mathrm{CoNi} / \mathrm{NC}$ and $\mathrm{CoNiP} / \mathrm{NC}$ materials, XPS tests were performed (Fig. S4 and Fig. 3). Fig. 4(a) indi-
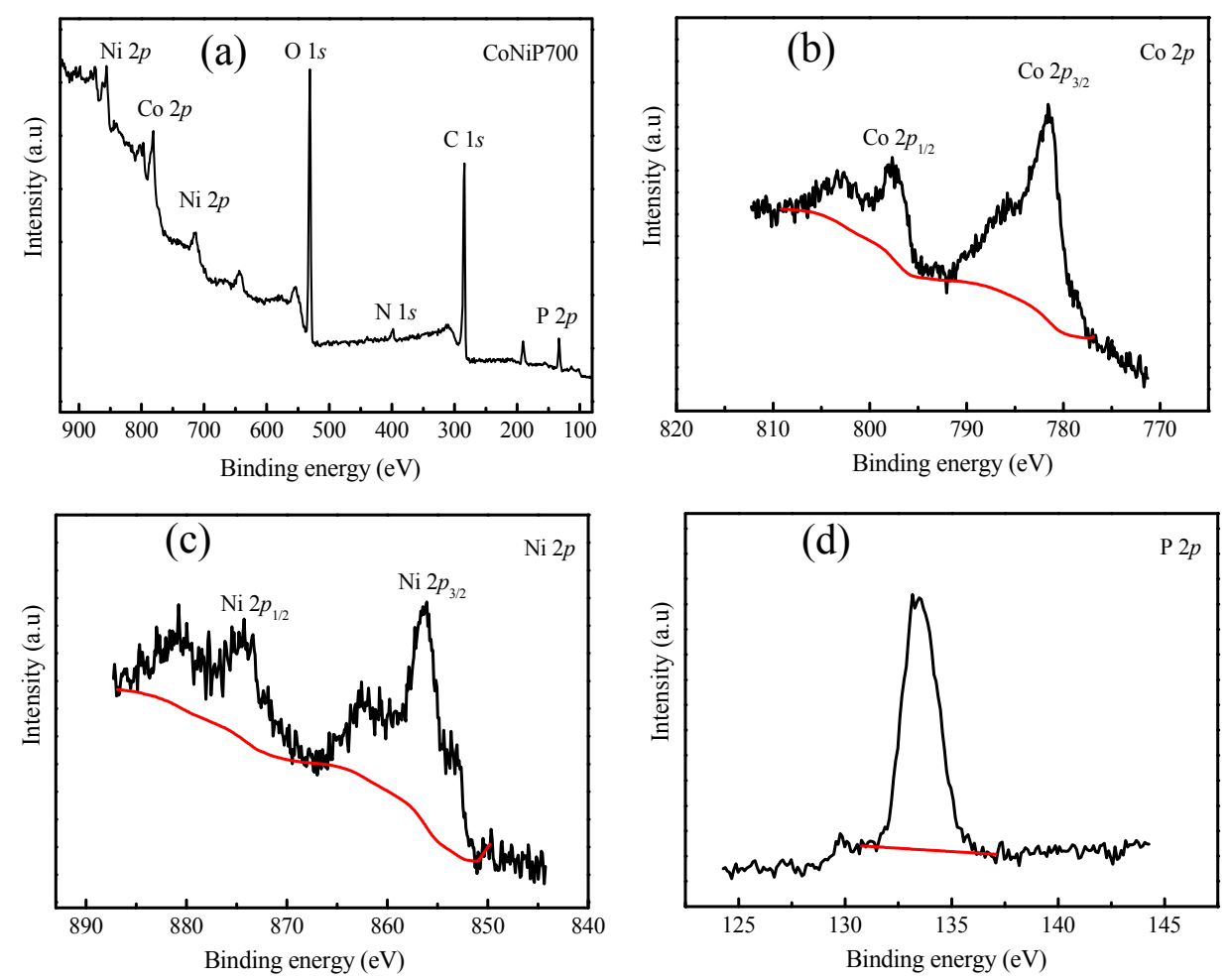

Fig. 3. XPS survey spectra of CoNiP/NC700 (a-d). 

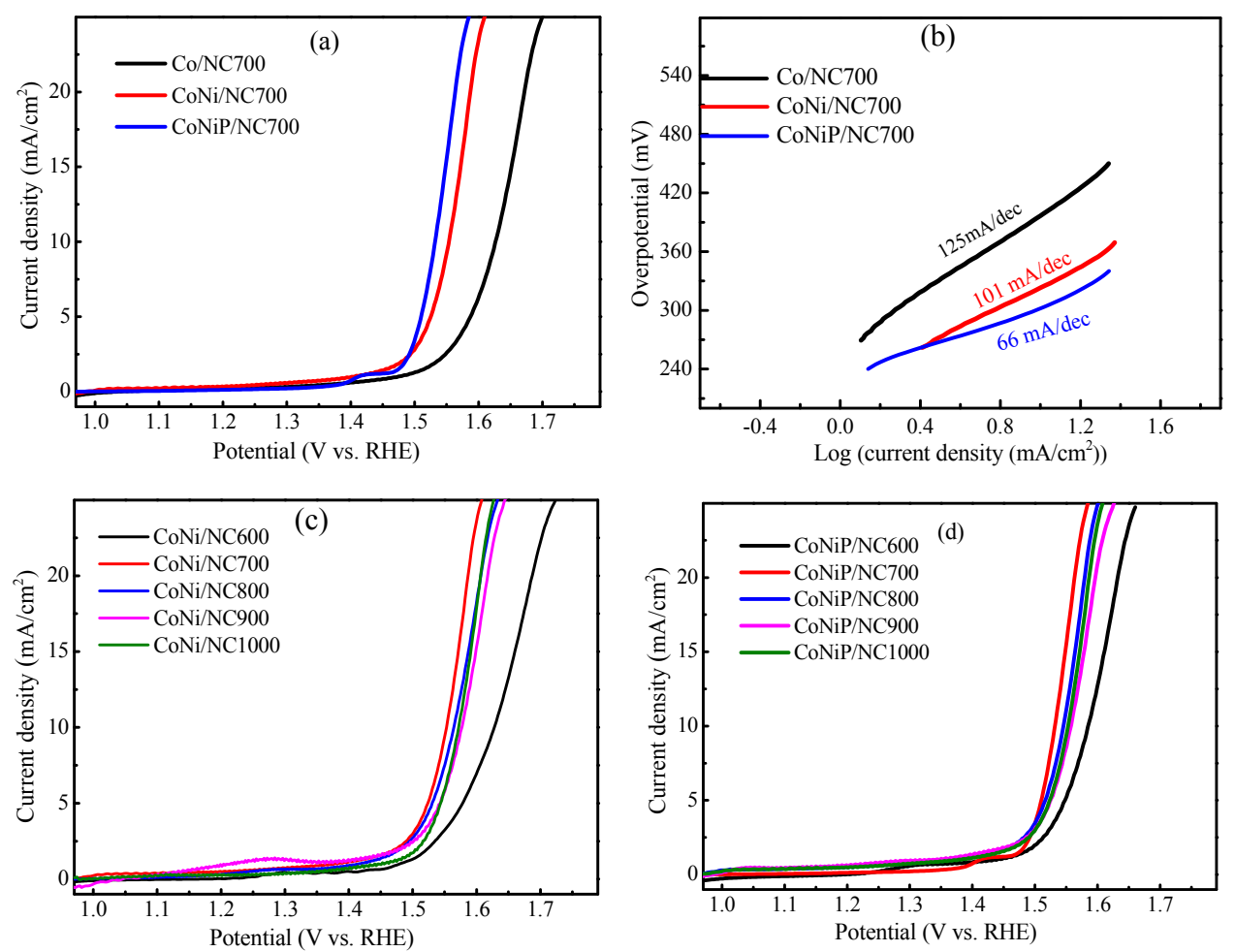

Fig. 4. (a) Polarization curves in $\mathrm{KOH}$ solution ( $1.0 \mathrm{~mol} / \mathrm{L}$; scan rate: $10 \mathrm{mV} / \mathrm{s}$ ); (b) Tafel plots derived from (a); (c) Polarization curves in KOH solution (1.0 mol/L; scan rate: $10 \mathrm{mV} / \mathrm{s}$ ); (d) Polarization curves in $\mathrm{KOH}$ solution $(1.0 \mathrm{~mol} / \mathrm{L}$; scan rate: $10 \mathrm{mV} / \mathrm{s})$.

cates the presence of $\mathrm{Co}, \mathrm{Ni}, \mathrm{P}, \mathrm{C}, \mathrm{N}$ and $\mathrm{O}$ in $\mathrm{CoNiP} / \mathrm{NC700}$. In addition, a small amount of $\mathrm{N}$ was detected in the CoNiP/NC700 samples, likely originating from the organic ligands, 2MI, in the MOFs. In the high-resolution Co $2 p$ XPS spectra (Fig. S4 and Fig. 3(c)), the CoNiP/NC700 samples show two main peaks at 781.6 and $793.7 \mathrm{eV}[5,17]$. The $\mathrm{Ni} 2 p$ spectrum of CoNi/NC800 exhibits two major peaks at 853.8 and $869.9 \mathrm{eV}$ (Fig. S4), which can be attributed to $\mathrm{Ni}^{8+}$ in the $\mathrm{Ni}-\mathrm{P}$ compound $[4,28]$. The Ni $2 p$ spectrum of CoNiP/NC700 exhibits two major peaks at 856.2 and $874.3 \mathrm{eV}$. For $\mathrm{Ni} 2 p_{1 / 2}$, the corresponding peak attributed to $\mathrm{Ni}^{\delta+}$ in the $\mathrm{Ni}-\mathrm{P}$ compound was observed at $869.7 \mathrm{eV}$ and peaks assigned to $\mathrm{Ni}^{2+}$ are located at $874.3 \mathrm{eV}$. A high-resolution spectrum of the $\mathrm{P} 2 p$ region shows a peak at $133.4 \mathrm{eV}$, reflecting the binding energy of $\mathrm{P} 2 p_{3 / 2}$ [5]. The XPS data demonstrate the successful chemical conversion of Co$\mathrm{Ni} / \mathrm{NC}$ to CoNiP/NC via the low-temperature gas phosphidation process.

The OER activity of the samples with the same mass loading of $0.255 \mathrm{mg} / \mathrm{cm}^{2}$ was evaluated in $\mathrm{KOH}$ solution $1.0 \mathrm{~mol} / \mathrm{L}$ at room temperature. Fig. 4(a) shows the polarization curves obtained by LSV measurements. For comparison, a bare GCE, ZIF-67, and ZIF-67Ni, were also studied (Fig. S5.1). The bare GCE, ZIF-67, and ZIF-67Ni had onset overpotentials of approximately 370,310 , and $330 \mathrm{mV}$ vs RHE, respectively, and an overpotentials of approximate 550, 450, and $440 \mathrm{mV}$, respectively, at a current density of $10 \mathrm{~mA} / \mathrm{cm}^{2}$, indicting negligible electrocatalytic activity and a low OER response. Fig. 4(a) shows that the polarization curve of CoNiP/NC700 exhibits the superior activity toward the OER compared to these of Co-
$\mathrm{Ni} / \mathrm{NC700}$ and Co/NC700, and shows an onset overpotential of approximate $220 \mathrm{mV}$ vs RHE and an overpotential of approximate $300 \mathrm{mV}$ at a current density of $10 \mathrm{~mA} / \mathrm{cm}^{2}$.

Meanwhile, the polarization curve of CoNiP/NC also exhibits the superior electrocatalytic activity toward the OER compared to these of CoNi/NC and Co/NC (Fig. S6), suggesting that the overpotential of CoNiP/NC is relatively lower than these of $\mathrm{CoNi} / \mathrm{NC}$ and $\mathrm{Co} / \mathrm{NC}$. The better electrocatalytic activity of the hybrid material can be attributed to the superior synergistic effect between $\mathrm{Co}, \mathrm{Ni}, \mathrm{P}$ and $\mathrm{C}$ due to their strong electron coupling interactions. The interconnected amorphous carbon anchored the active Co compounds preventing aggregation and afforded conducting channels for electron transfer. It should be noted that the overpotential for the OER activity of CoNiP/NC700 is much lower than that of most reported metal-free and transition metal oxides OER catalysts (Table S1, Supporting Information). Among reported electrocatalytic materials, the CoNiP/NC700 showed the highest electrocatalytic activity (Fig. 4(d)), due to its MOF-derived porous carbon structure and $\mathrm{N} / \mathrm{Co} / \mathrm{Ni}$-doping effect $[27,29]$. The Tafel plots of Co/NC700, CoNi/NC700 in Fig. 4(b) were derived from the polarization curves in Fig. 4(a). A lower Tafel slope value indicates more rapid OER kinetics and significant chemical and electronic coupling [30]. In comparison to Co/NC700 and Co$\mathrm{Ni} / \mathrm{NC700}$, the CoNiP/NC700 electrocatalyst exhibits a lower onset potential and higher current density for the OER. It is clear that CoNiP/NC700 shows the lowest Tafel slope (Fig. 4(b)) among the materials tested. The superior electrocatalytic activity of the hybrid material can be attributed to the synergis- 


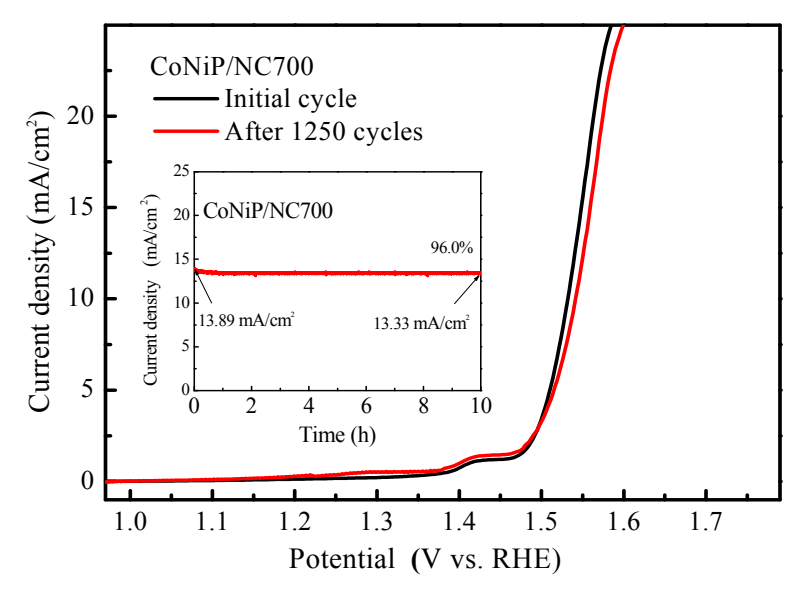

Fig. 5. Polarization curves before (black) and after (red) $10 \mathrm{~h}$ of electrocatalytic OER operation.

tic effect between $\mathrm{Co}, \mathrm{Ni}, \mathrm{P}$ and $\mathrm{C}$ due to their strong electron coupling interactions. The interconnected amorphous carbon anchored the active Co compounds preventing aggregation and afforded conducting channels for electron transfer. Furthermore, Figs. S6.1-S6.4 show the various polarization curves and Tafel plots obtained under different conditions. The excellent stability of the electrode was confirmed by the polarization curve stability after continuous potential sweeps (Fig. 5).

A negligible difference was observed in the polarization curves after $10 \mathrm{~h}$ of continuous testing in $1.0 \mathrm{~mol} / \mathrm{L} \mathrm{KOH}$. These results indicate that $\mathrm{CoNiP} / \mathrm{NC7} 00$ exhibits the excellent stability in alkaline solution. The stability of CoNiP/NC700 catalysts for the OER was measured by the $i-t$ tests at a constant potential of $1.53 \mathrm{~V}$ vs. RHE. It is clear that the CoNiP/NC700 catalysts annealed at $700{ }^{\circ} \mathrm{C}$ exhibit superior durability, with negiligible decay (4.0\%) in OER activity during $10 \mathrm{~h}$ of continuous operation (Fig. 5).

\section{Conclusions}

CoNiP/NC materials were successfully developed as efficient electrocatalysts for the OER by carbonization and phosphorization calcinations of preformed Co-based MOFs. The CoNiP/NC700 electrocatalyst exhibited excellent catalytic performance with a low overpotential of $300 \mathrm{mV}$ at a current den- sity of $10 \mathrm{~mA} / \mathrm{cm}^{2}$ and Tafel slopes of $66 \mathrm{mV} / \mathrm{dec}$ in alkaline electrolytes, due to its MOF-derived porous carbon structure and the N/Co/Ni-doping effect. The CoNiP/NC electrocatalyst obtained at different temperatures exhibited better electrocatalytic activity than these of the $\mathrm{Co} / \mathrm{NC}$ and $\mathrm{CoNi} / \mathrm{NC}$ materials. In addition, the facile synthesis method based on MOF templates to for the preparation of CoNiP/NC is low cost and uses abundant resources, providing a synthetic method for practical applications. The catalysts developed herein are expected to find use in clean energy devices, and the synthesis methods could be to extended to other materials with different structures and properties, especially for bimetallic or trimetallic hybrid composites.

\section{References}

[1] S. Sinha, S. S. Chandel, Renew. Sust. Energy Rev., 2015, 50, 755-769.

[2] Z. X. Zhou, F. He, Y. F. Shen, X. H. Chen, Y. R. Yang, S. Q. Liu, T. Mori, Y. J. Zhang, Chem. Commun., 2017, 53, 2044-2047.

[3] T. H. Zhou, Y. H. Du, D. P. Wang, S. M. Yin, W. G. Tu, Z. Chen, A. Borgna, R. Xu, ACS Catal., 2017, 7, 6000-6007.

[4] W. C. Xu, H. X. Wang, Chin. J. Catal., 2017, 38, 991-1005.

[5] M. J. Liu, J. H. Li, ACS Appl. Mater. Interfaces, 2016, 8, 2158-2165.

[6] W. F. Chen, J. T. Muckerman, E. Fujita, Chem. Commun., 2013, 49, 8896-8909.

[7] Y. Zheng, Y. Jiao, M. Jaroniec, S. Z. Qiao, Angew. Chem. Int. Ed., 2015, $54,52-65$.

[8] X. Long, J. K. Li, S. Xiao, K. Y. Yan, Z. L. Wang, H. N. Chen, S. H. Yang, Angew. Chem. Int. Ed., 2014, 53, 7584-7588.

[9] M. A. Oliver-Tolentino, J. Vazquez-Samperio, A. Manzo-Robledo, R. de Guadalupe González-Huerta, J. L. Flores-Moreno, D. Ramirez-Rosales, A. Guzman-Vargas, J. Phys. Chem. C, 2014, 118, 22432-22438.

[10] B. Dong, X. Zhao, G. Q. Han, X. Li, X. Shang, Y. R. Liu, W. H. Hu, Y. M. Chai, H. Zhao, C. G. Liu, J. Phys. Chem. A, 2016, 4, 13499-13508.

[11] H. Li, Y. D. Shao, Y. T. Su, Y. H. Gao, X. W. Wang, Chem. Mater., 2016, $28,1155-1164$.

[12] Y. B. Huang, M. Zhang, P. Liu, F. L. Cheng, L. S. Wang, Chin. J. Catal., 2016, 37, 1249-1256.

[13] H. Y. Jin, S. J. Mao, G. P. Zhan, F. Xu, X. B. Bao, Y. Wang, J. Mater. Chem. A, 2017, 1078-1084.

[14] S. Patra, R. Choudhary, E. Roy, R. Madhuri, P. K. Sharma, Nano Energy, 2016, 30, 118-129.

[15] K. M. Nam, E. A. Cheon, W. J. Shin, A. J. Bard, Langmuir, 2015, 31,

\section{Graphical Abstract}

Chin. J. Catal., 2018, 39: 982-987 doi: 10.1016/S1872-2067(18)63030-X

\section{CoNiP/NC polyhedrons derived from cobalt-based zeolitic} imidazolate frameworks as an active electrocatalyst for oxygen evolution

Jintang Li *, Guiqing Du, Xian Cheng, Pingjing Feng, Xuetao Luo Xiamen University

Schematic diagram to illustrate the OER catalytic principles on CoNiP /NC polyhedrons. Step I: transformation of ZIF-67 into CoNi/NC by a facile etching and deposition process and carbonization; Step II: formation of CoNiP/NC by phosphatizing CoNi/NC.

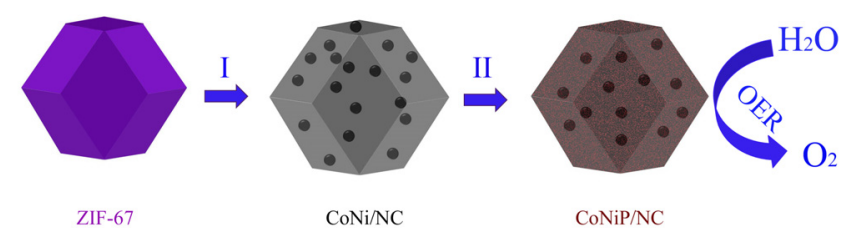


10897-10903.

[16] F. X. Yin, G. R. Li, H. Wang, Catal. Commun., 2014, 54, 17-21.

[17] X. B. Yang, J. Chen, Y. Q. Chen, P. J. Feng, H. X. Lai, J. T. Li, Nano-Micro Lett., 2018, 10, 15-25

[18] A. U. Czaja, N. Trukhan, U. Muller, Chem. Soc. Rev., 2009, 38, 1284-1293.

[19] Y. Zhou, J. L. Long, Y. W. Li, Chin. J. Catal., 2016, 37, 955-962.

[20] S. B. Wang, J. L. Lin, X. C, Wang, Phys. Chem. Phys., 2014, 16, 14656-14660.

[21] M. B. Solomon, T. L. Church, D. M. D'Alessandro, CrystEngComm, 2017, 19, 4049-4065.

[22] K. Shen, X. D. Chen, J. Y. Chen, Y. W. Li, ACS Catal., 2016, 6, 5887-5903.

[23] H. B. Zhang, G. G. Liu, L. Shi, H. M. Liu, T. Wang, J. H. Ye, Nano Ener- gy, 2016, 22, 149-168.

[24] Y. Hou, Z. H. Wen, S. M. Cui, S. Q. Ci, S. Mao, J. H. Chen, Adv. Funct. Mater., 2015, 25, 872-882.

[25] Y. Lu, T. Y. Wang, X. R. Li, G. X. Zhang, H. G. Xue, H. Pang, RSC Adv., 2016, 6, 87188-87212.

[26] Z. Jiang, Z. P. Li, Z. H. Qin, H. Y. Sun, X. L. Jiao, D. R. Chen, Nanoscale, 2013, 5, 11770-11775.

[27] P. L. He, X. Y. Yu, X. W. Lou, Angew. Chem. Int. Ed., 2015, 56, 5590-5595.

[28] Y. Feng, X. Y. Yu, U. Paik, Chem. Commun., 2016, 52, 1633-1636.

[29] D. R. Sun, L. Ye, F. X. Sun, H. Garcia, Z. H. Li, Inorg. Chem., 2017, 56, 5203-5209.

[30] A. Mahmood, W. H. Guo, H. Tabassum, R. Q. Zou, Adv. Energy Mater., 2016, 6, 1600423.

\title{
钴基类沸石咪唑酯框架材料衍生的析氧反应活性催化剂
}

\author{
李锦堂", 都桂卿, 程显, 封平净, 罗学涛 \\ 厦门大学材料学院福建省先进材料重点实验室, 福建厦门361005
}

\begin{abstract}
摘要: 析氧反应 (OER) 在能量转换和储存技术中扮演着重要角色, 例如在水分解和金属空气电池中, 电催化剂的发展是主 要任务. 本文采用钴基的类沸石咪唑酯骨架结构材料 (ZIFs) 作为前驱体, 在氩气保护气氛下, 成功制备了氮掺杂钴镍磷多 孔碳多面体电催化剂 (CoNiP/NC). 首先, 采用 ZIF-67 作为前驱体, 将 ZIF-67 和六水合硝酸镍按照一定比例在乙醇溶液中 搅拌 $30 \mathrm{~min}$, 达到掺杂镍的目的, 然后将其在不同温度下抜烧, 得到的样品在 $300^{\circ} \mathrm{C}$ 氞气保护气氛下磷化, 得到最终产物. 所有电催化剂均通过控制碳化和磷化作用温度获得. 通过对样品 ZIF-67Ni 进行 EDS 分析, 证明镍成功负载到 ZIF-67 上, XPS 结果也证明了这一点. 由扫描电镜图可以看出, 前驱体 ZIF-67 在负载 Ni 之后, 样品表面形貌发生明显变化, 表面变得 粗糙, 有明显的条文. 磷化后样品的XRD 结果说明磷化方法是成功的, 同时 XPS 结果表明样品中有 P 元素存在. 从扫描 电镜图片可以明显看出, 样品在煅烧之后表面形貌发生明显变化, 由棱角明显变为表面粗粘, 但是并未发生明显的团聚现 象. XPS 显示, 样品 CoNiP/NC700 (700 指㶲烧温度 $\left.\left({ }^{\circ} \mathrm{C}\right)\right)$ 中存在钴、镍、磷、碳、氮、氧这六种元素, 另外还分析了其高分 辨图. 结果显示, 电催化剂 CoNiP/NC700 表现出优越的电催化效率, 在碱性溶液的电流密度 $10 \mathrm{~mA} / \mathrm{cm}^{2}$ 条件下, 其开路电 压约为 $220 \mathrm{mV}$, 过电位约为 $300 \mathrm{mV}$. 掺杂镍之后的样品性能比煅烧 ZIF-67 的样品好, 说明镍对于提高析氧反应效率有 益; 同样, 磷化之后样品的 OER 性能也有所提高. 相比较而言, 对于磷化之后的样品, 煅烧温度是 $700{ }^{\circ} \mathrm{C}$ 时, OER 催化效 率最好. 磷化杂化材料优越的电催化活性是由于其强的电子耦合相互作用而产生的协同效应, 在镍、磷、碳等方面具有较 强的协同效应. 相互联系的非定形碳不仅固定了活性碳化合物以避免聚集, 而且还为电子转移提供了传导通道. 对样品 $\mathrm{CoNiP} / \mathrm{NC} 700$ 进行了稳定性测试, 结果表明其稳定性较好, 在循环 $10 \mathrm{~h}$ 之后, 活性仅下降了 $4 \%$. 这一研究表明, 该复合电 催化剂可能是电催化氧化反应的一个很有前景的候选催化剂.
\end{abstract}

关键词: ZIF-67; 碳化; 磷化; 电催化; 析氧反应

收稿日期: 2017-12-19. 接受日期: 2018-01-21. 出版日期: 2018-05-05.

*通讯联系人. 电话: 18030105513; 电子信箱: leetjt@xmu.edu.cn

基金来源：国家自然科学基金 (51204143, 51334004); 福建省科技创新平台(2006L2003).

本文的电子版全文由Elsevier出版社在ScienceDirect上出版(http://www.sciencedirect.com/science/journal/18722067). 